\title{
The characteristics of habitats colonized by three species of Lymnaea (Mollusca) in swampy meadows on acid soil : their interest for control of fasciolosis
}

\author{
C. Vareille-Morel ${ }^{1}$ \\ G. Dreyfuss ${ }^{2}$ \\ D. Rondelaud ${ }^{3}$
}

Keywords : acid soil, fasciolosis, habitats, Lymnaea, swampy meadow.

Malacological investigations were carried out in 53 meadows on acid soil to identify the characteristics of habitats colonized by lymnaeid snails. These meadows are located in three different geographical districts (Basse-Marche, Monts d'Ambazac, Plateaux de la Vienne) in the Haute-Vienne Department (central France). Lymnaea truncatula lived at the distal extremity of open drainage furrows; $L$. glabra inhabited the middle part of furrows and $L$. palustris lived in the central ditch. The mean area of $L$. truncatula habitats ranged from 2.8 to $4.8 \mathrm{~m}^{2}$ in relation to the district studied and was smaller than those of L. glabra (a mean of 3.6 to $7.2 \mathrm{~m}^{2}$ ) and L. palustris (10.3 to $19.3 \mathrm{~m}^{2}$ ). Mean intervals between the sites occupied by $L$. truncatula and $L$. glabra ranged from 6.3 to $12.3 \mathrm{~m}$; they were greater between the sites occupied by $L$. glabra and L. palustris (11.6 to $15.4 \mathrm{~m}$ ). Finally, the mean densities of $L$. truncatula in June ranged from 11.4 to $19.8 / \mathrm{m}^{2}$ in relation to the district studied ; those of $L$. glabra ranged from 22.6 to $27.0 \mathrm{snails} / \mathrm{m}^{2}$, whereas in L. palustris, they ranged from 6.3 to $8.8 \mathrm{snails} / \mathrm{m}^{2}$. The mean values of these first two parameters were significantly lower in the habitats located in Monts d'Ambazac than those recorded in the two other districts. Implications of these results for fasciolosis control are discussed.

Les caractéristiques des habitats colonisés par trois espèces de Lymnaea (Mollusques) dans les prairies marécageuses sur sol acide : leur intérêt pour le contrôle de la fasciolose

Mots-clés : mollusques, Lymnaea, fasciolose, habitats, Haute-Vienne, prairie marécageuse, sol acide.

Des investigations malacologiques ont été réalisées dans 53 prairies afin de déterminer les caractéristiques des habitats colonisés par des mollusques Lymnaeidae. Ces prairies sont localisées dans trois secteurs géographiques différents du département de la Haute-Vienne (Basse-Marche, Monts d'Ambazac, Plateaux de la Vienne). Lymnaea truncatula vit à l'extrémité distale des rigoles de drainage superficiel ; $L$. glabra colonise la partie moyenne des mêmes rigoles et $L$. palustris vit dans le fossé central. La superficie moyenne des habitats de $L$. truncatula varie de 2,8 à $4,8 \mathrm{~m}^{2}$ selon le secteur étudié et est plus petite que celles relevées dans les gîtes de $L$. glabra $\left(3,6\right.$ à $\left.7,2 \mathrm{~m}^{2}\right)$ ou de $L$. palustris $\left(10,3\right.$ à $\left.19,3 \mathrm{~m}^{2}\right)$. Les distances moyennes entre les sites occupés par $L$. truncatula et $L$. glabra.fluctuent entre 6,3 et $12,3 \mathrm{~m}$; elles sont plus grandes entre les zones coloniées par $L$. glabra et $L$. palustris (11,6 à 15,4 m). Enfin, les densités moyennes de $L$. truncatula en juin varient de 11,4 à $19,8 / \mathrm{m}^{2}$ selon le secteur d'étude ; celles de $L$. glabra fluctuent entre 22,6 et 27,0 mollusques $/ \mathrm{m}^{2}$ alors que chez $L$. palustris, elles se situent entre 6,3 et 8,8 mollusques $/ \mathrm{m}^{2}$. Les moyennes des deux premiers paramètres sont significativement plus faibles dans les gîtes situés dans les Monts d'Ambazac que celles enregistrées dans les deux autres secteurs. Les implications de ces résultats dans le contrôle de la fasciolose sont discutées.

\section{Introduction}

Prevention of fasciolosis in cattle involves a number of measures. One measure is control of the snails that

\footnotetext{
1. Faculté des Sciences, Laboratoire de Malacologie Appliquée, 123 avenue Albert Thomas, F-87060 Limoges Cedex.

2. Faculté de Pharmacie, Laboratoire de Parasitologie, 2 rue du Docteur Raymond Marcland, F-87025 Limoges Cedex.

3. Faculté de Médecine, Laboratoire d'Histopathologie Parasitaire, 2 rue du Docteur Raymond Marcland, F-87025 Limoges Cedex.
}

act as intermediate hosts in the life cycle of the liver fluke, Fasciole hepatica (Linnaeus). In France, the main snail host in Lymnaea truncatula (O.F. Müller) which may be infected at any age. Other Lymnaea species such as L. glabra (O.F. Müller) or L. palustris (O.F. Müller) are also present in pastures and may assure the complete larval development of $F$. hepatica when the snails are exposed to miracidia only in the days following their hatching (Kendall 1950, Busson et al. 1982). Various methods to control these intermediate hosts have been proposed, including agronomic 
techniques (drainage), the use of molluscicides (reviewed by Taylor 1965 and Euzeby 1971), or the introduction of carnivorous snails in lymnaeid habitats (Rondelaud 1975, 1981). However, except for drainage, these methods have seldom been used in L. truncatula habitats in French meadows.

L. truncatula is frequent in swampy meadows on acid soil. In the Haute-Vienne Department (central France), snail habitats are confined to the peripheral extremities of open drainage furrows and ditches. However, two other lymnaeid species (L. glabra, L. palustris) live in other isolated habitats in the lower levels of the same drainage networks (Bouix-Busson \& Rondelaud 1984, Vareille et al. 1996). Colonies of each Lymnaea species were found to be isolated from those of other species with no overlap. In view of these findings, the question arose as to whether fasciolosis control might be affected by isolating Lymnaea habitats from other parts of the meadow and, subsequently, from cattle. Preliminary studies on the characteristics of the habitats of each species would be necessary to determine conditions in which this management technique could be used. The present paper gives the results of a quantitative study of 53 acid soil meadows in the Haute-Vienne Department, each with an open drainage network.

\section{Stations studied}

The 53 studied meadows were distributed among three geographical districts. In Basse-Marche, 15 hygro-mesophilous meadows were located within a $7 \mathrm{~km}$ radius around the town of Bellac (Altitude : 190-268 $\mathrm{m})$. In the Monts d'Ambazac district there were 23 meadows in the communes of Compreignac, Nantiat and Thouron (Altitude : $300-420 \mathrm{~m}$ ). The third district, Plateaux de la Vienne, included 15 meadows within a $10 \mathrm{~km}$ radius of the Limoges city (Altitude : 274$370 \mathrm{~m}$ ).

The subsoil comprises crystalline or metamorphic rocks. Twenty meadows in Monts d'Ambazac have underlying two-mica granite. The substratum of the others is more variable, although migmatites underlaid 20 meadows. All soils are hydromorphous. Water is running in the furrows from mid-October to the end of June or the beginning of July, with summer drying of habitats from mid-June to the end of August. Water is oligocalcic, with a calcium ion content ranging from 3 to $26.8 \mathrm{mg} / \mathrm{l}$ and a $\mathrm{pH}$ from 5.5 to 7.8 (Guy et al. 1996). The habitats of L. truncatula and L. glabra contained few or no mud, but mud is more frequent in the $L$. palustris habitats and usually constitutes a layer from 1 to $3 \mathrm{~cm}$.
Most meadows are in valleys and have open drainage systems.Typically, a central drainage ditch runs from a spring, emptying into a brook. From this central ditch, smaller furrows lead off, draining water from the meadow (Fig. 1). The length of the central ditch ranges from 95 to $135 \mathrm{~m}$, their width $50-75 \mathrm{~cm}$ and their depth $20-25 \mathrm{~cm}$. The length of furrows is varying from 30 to $80 \mathrm{~m}$ in Monts d'Ambazac meadows, and from 60 to $100 \mathrm{~m}$ in the meadows of the other two districts. Their width and depth are $40-45 \mathrm{~cm}$ and $12-15 \mathrm{~cm}$, respectively.

The climate is essentially continental, but under some oceanic influence, with wet weather coming from the west. Average annual rainfall ranged from 800 to $1,100 \mathrm{~mm}$, depending on altitude. Average annual temperature was $10^{\circ}$ to $10.5^{\circ} \mathrm{C}$, with a decrease of $0.55^{\circ} \mathrm{C}$ for each increasing $100 \mathrm{~m}$ (Vilks 1991).

Hygrophilous vegetation in the Basse-Marche meadows belongs to the Junco-Cynosuretum cristati association, although Cynosurus cristatus is rare. In the Monts d'Ambazac meadows, the vegetation belongs to the Caro verticillati-Juncetum acutiflori association. The plant community of the Plateaux de la Vienne meadows belongs also to the Caro verticillati-Juncetum acutiflori association but Carum verticillatum is absent. A total of 43 meadows were grazed by cattle over the year of the study, and the 10 others by sheep. Hygrophilous vegetation was mowed in August or September and the drainage furrows and ditches were cleared in October-November.

\section{Methods}

Two campaigns (1994-1995) were carried out to study the habitats of Lymnaea species in June-July because of the highest snail densities during these two months. The distributions of the three lymnaeid species were first identified in 1994 by following the open drainage systems, from the terminal extremity of each furrow until the mouth of the drainage ditch in the brook. Investigations were subsequently performed in 1995 to determine i) the length of furrow (or ditch) inhabited by each species, ii) the surface area of each snail location, including places trampled by cattle, iii) the distance between populations of different species in the same drainage system, and iv) the snail density per $\mathrm{m}^{2}$ of habitat in June. The total surface area of every 53 meadows was also calculated to determine the percentage of the surface area occupied by each species.

The values of the parameters i), ii), and iii) were first measured in each meadow before snail count. Snails 


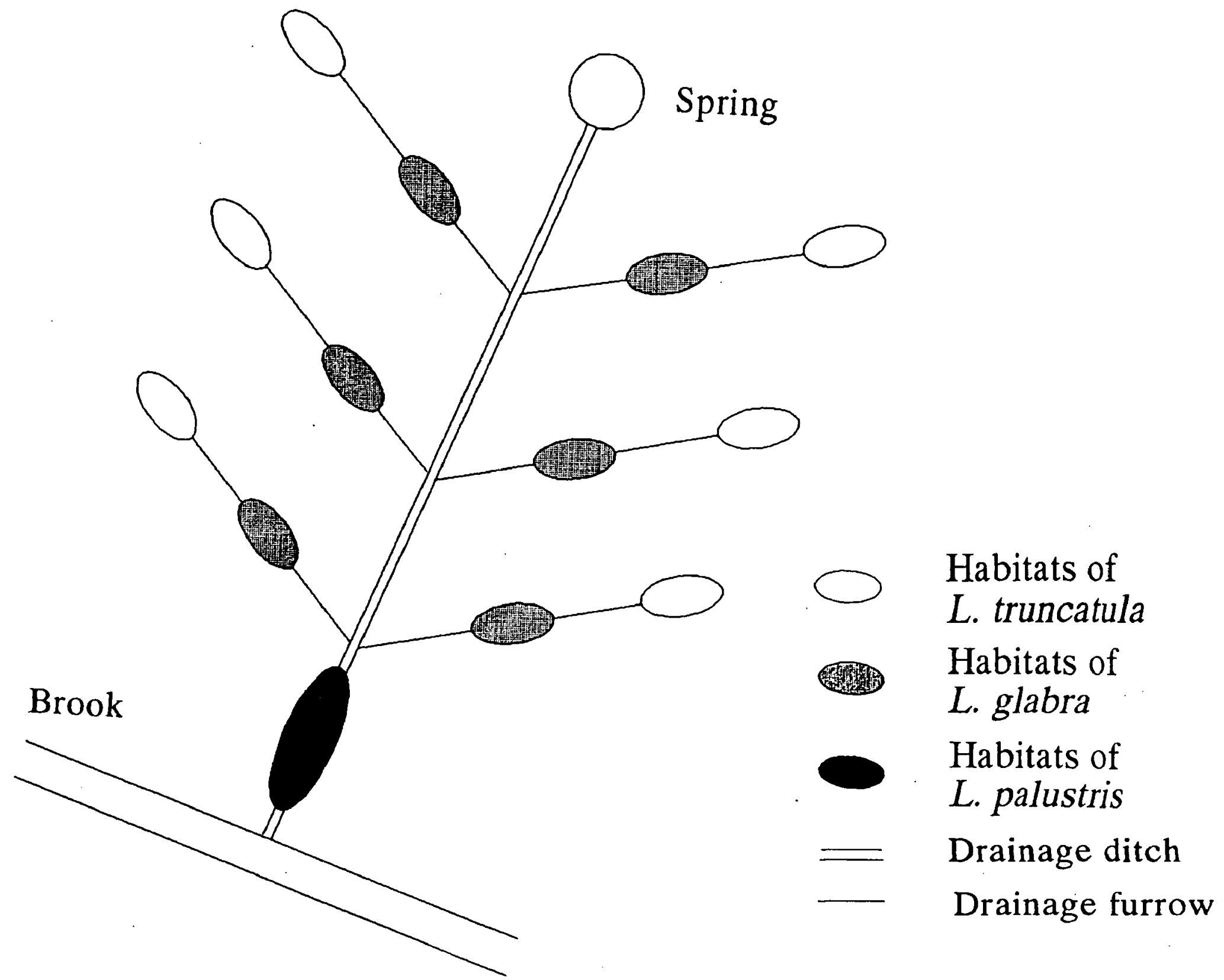

Fig. 1. Generalized location of the habitats of the three lymnaeid species in the open drainage systemps of meadows on acid soil in the Haute-Vienne Department, France.

Fig. 1. Localisation générale des habitats des trois espèces de limnées sur les réseaux de drainage superficiel dans les prairies sur sol acide dans le département de la Haute-Vienne.

were then collected in the emersed zones of each area as well as in stagnant or shallow waters (no more than $5 \mathrm{~cm}$ in depth during the study period). The snail search in each habitat and subsequent count were first made by one person, over 15 to $20 \mathrm{~min}$. A control in each habitat was subsequently performed over 10 to $15 \mathrm{~min}$ by a second person to collect any snails that had escaped the first investigator. All searches and counts were made before the summer growth of hygrophilous plants, which occurred in mid-July. Lastly, the calculation of snail density was performed for each Lymnaea species and each habitat by dividing the total number of snails collected by the corresponding surface area.
Mean values and standard deviations were calculated from the individual meadow values for each parameter, taking into account the geographical district and snail species. These values were then analyzed by oneway analysis of variance (Stat-Itcf 1988).

\section{Results}

The figure 1 represents the location of habitats for each Lymnaea species along the drainage network. $L$. truncatula inhabited the extremity of the 231 furrows and the surrounding areas. The two other species are less frequent : L. glabra was found only in the middle part of 127 furrows (out of 231) and L. palustris in the 
most downstream part of 9 central ditches and sometimes, in the lower part of the first furrows.

The mean values and standard deviations of parameters recorded in the sites occupied by $L$. truncatula, $L$. glabra and L. palustris are given in the tables 1,2, and 3 , respectively.

The mean length of the furrow inhabited by L. truncatula populations ranged from 3.0 to $5.0 \mathrm{~m}$. The mean values were higher for the other two species : from 7.2 to $14.3 \mathrm{~m}$ for L. glabra, 5.0 to $9.9 \mathrm{~m}$ for L. palustris. For each species, the length of habitats was significantly shorter in the Monts d'Ambazac district than in the two others (L. truncatula: $\mathrm{F}_{2.228}=4.59, \mathrm{P}<0.05$; L. glabra $: \mathrm{F}_{2.124}=6.37, \mathrm{P}<0.01 ;$ L. palustris $: \mathrm{F}_{2.6}=$ $17.50, \mathrm{P}<0.01)$. In the opposite, there was no significant difference between the values of Basse-Marche and Plateaux de la Vienne, whatever the lymnaeid species.

The surface areas of habitats inhabited by $L$. truncatula $\left(2.8\right.$ to $\left.4.8 \mathrm{~m}^{2}\right)$ and by L. glabra $\left(3.6\right.$ to $\left.7.2 \mathrm{~m}^{2}\right)$ were clearly lower than for $L$. palustris ( 10.3 to $19.3 \mathrm{~m}^{2}$ per habitat). For each species, the areas were significantly lower in Monts d'Ambazac district than in the other two geographical zones (L. truncatula $: \mathrm{F}_{2.228}=$ $6.37, \mathrm{P}<0.01 ;$ L. glabra $: \mathrm{F}_{2.124}=33.40$, $\mathrm{P}<0.001 ;$ L. palustris : $\left.\mathrm{F}_{2.6}=60.54, \mathrm{P}<0.001\right)$. This occupied area did not differ significantly in BasseMarche and in Plateaux de la Vienne for L. truncatula or L. palustris, but did so for L. glabra $\left(\mathrm{F}_{2.124}=6.79\right.$, $\mathrm{P}<0.01)$. The total area occupied by lymnaeid snails, regardless of species, was only a tiny proportion of the overall meadow area.

The mean intervals between the sites occupied by $L$. truncatula and L. glabra ranged from $6.3 \mathrm{~m}$ (in Monts d'Ambazac) to $12.3 \mathrm{~m}$ (in Basse-Marche), with a significant difference between Monts d'Ambazac and each of the two other districts. Intervals between $L$. glabra and $L$. palustris were higher : 11.6 to $15.4 \mathrm{~m}$, but with no significant differences between districts.

In June the snail ranged from 11.4 to $19.9 / \mathrm{m}^{2}$ for $L$. truncatula, from 22.6 to $27.2 / \mathrm{m}^{2}$ for L. glabra, and from 6.3 to $8.8 / \mathrm{m}^{2}$ for L. palustris. No significant differences in the mean densities of each species between the three districts were noted. The comparison of mean densities of each species was also made in relation with the nature of substratum and the altitude. There were no significant differences.

\section{Discussion}

In the L. truncatula habitats located on sedimentary soils, the snail lived in widespread habitats. For example, the surface of colonized sites was 22 ha in the region of Gembloux, Belgium (Van den Bruel 1968), whereas the four studied farms stretched over $103 \mathrm{ha}$, in which $L$. truncatula was present in $21 \%$ of meadows. The high values were also present in the work by Pécheur (1974) : the surface of snail habitats was 1 to 4 ha, and snails colonized $5 \%$ to $40 \%$ of the meadow surface in the three farms studied in Belgium. Moens (1982) and Rondelaud (1988) gave clearly lower surfaces for habitats on sedimentary soil, with $99.6 \mathrm{~m}^{2}$ per habitat for the former author and $42.5 \mathrm{~m}^{2}$ for the latter. In contrast, the results given by Rondelaud (1977) in the department of Haute-Vienne were closer to the values we obtained. In 23 habitats colonized by $L$. truncatula, this author reported a mean surface of $9.1 \mathrm{~m}^{2}$. A comparison of these data demonstrated that $L$. truncatula habitats had a limited surface in opposite to that recorded in snail habitats located in sedimentary soil regions.

The density of $L$. truncatula in its habitats was also dependent on the nature of the subsoil. In habitats located in sedimentary soil, most snail densities in JuneJuly ranged from 20 to $101 \mathrm{~L}$. truncatula $/ \mathrm{m}^{2}$ (Van den Bruel 1968, Pécheur 1974, Smith \& Wilson 1980, Moens 1982). In acid soil habitats, snail densities were clearly lower, with a mean value of 25.6 snails $/ \mathrm{m}^{2}$ in the work by Rondelaud (1977), and mean densities from 11.4 to $19.8 / \mathrm{m}^{2}$ in the present study. From this comparison, it can be assumed that habitats on acid soil were less populated than those on sedimentary soil. The presence of the terrestrial carnivorous snail, Zonitoides nitidus (O.F. Müller), in the hygrophilous zones of acid soil meadows (Rondelaud 1975) may give an explanation, for $Z$. nitidus ate numerous emersed $L$. truncatula in July and therefore limited the size of $L$. truncatula populations.

Little information concerning the habitats of L. glabra is available and only concerned to habitats on acid soil. Bouix-Busson \& Rondelaud (1984) reported a mean surface of $10 \mathrm{~m}^{2}$ (limits : $7.7-22.8 / \mathrm{m}^{2}$ ) in the Haute-Vienne Department. Mean densities ranged from 15.9 to 19.8 snails $/ \mathrm{m}^{2}$ (Rondelaud 1982) and reached 39 snails $/ \mathrm{m}^{2}$ in the study by Bouix-Busson $\&$ Rondelaud (1984), whereas they ranged from 22.6 to 27.2 snails $/ \mathrm{m}^{2}$ in our study. Our results agree with those of these authors.

The surface area of habitats occupied by $L$. palustris was lower in the report by Dreyfuss et al. (1994) than in our study : a mean of $10.1 \mathrm{~m}^{2}$ vs $10.3-19.3 \mathrm{~m}^{2}$. Snail density was clearly lower in our observations than in the report of Dreyfuss et al. : $6.3-8.8$ snails $/ \mathrm{m}^{2}$ vs $40.7 / \mathrm{m}^{2}$. These differences can be explained by the 
Table 1. Characteristics of sites inhabited by Lymnaea truncatula and the total area of the meadows on acid soil. a (mean value). b (standard deviation.

Tableau 1. Caractéristiques des sites colonisés par Lymnaea truncatula et la superficie totale des prairies sur sol acide. a (moyenne). b (écart type).

\begin{tabular}{llll}
\hline Parameters & Basse-Marche & Monts d'Ambazac & Plateaux de la Vienne \\
\hline Number of meadows & 15 & 23 & 15 \\
Total number of populations & 68 & 90 & 73 \\
Length of habitat $: \mathrm{a} \pm \mathrm{b}(\mathrm{m})$ & $4.6 \pm 1.9$ & $3.0 \pm 0.8$ & $5.0 \pm 2.1$ \\
Surface area of habitats $: \mathrm{a} \pm \mathrm{b}\left(\mathrm{m}^{2}\right)$ & $4.2 \pm 1.2$ & $2.8 \pm 0.8$ & $4.8 \pm 1.4$ \\
Snail density in each habitat $: \mathrm{a} \pm \mathrm{b}$ & $19.8 \pm 8.5$ & $11.4 \pm 6.5$ & $14.4 \pm 6.8$ \\
Total area occupied $\left(\mathrm{m}^{2}\right)$ & 286 & 252 & 350 \\
Total area of meadows $(\mathrm{ha})$ & 36.5 & 28.7 & 20.2 \\
Percentage of meadow & $0.08 \%$ & $0.09 \%$ & $0.17 \%$ \\
occupied by snails & & & \\
\hline
\end{tabular}

Table 2. Characteristics of sites inhabited by Lymnaea glabra and the total area of the meadows on acid soil. a (mean value). b (standard deviation.

Tableau 2. Caractéristiques des sites colonisés par Lymnaea glabra et la superficie totale des prairies sur sol acide. a (moyenne). b (écart type).

\begin{tabular}{llll}
\hline Parameters & Basse-Marche & Monts d'Ambazac & Plateaux de la Vienne \\
\hline Number of meadows & 15 & 23 & 15 \\
Total number of populations & 68 & 90 & 73 \\
Length of habitat $: \mathrm{a} \pm \mathrm{b}(\mathrm{m})$ & $14.3 \pm 6.2$ & $7.2 \pm 2.3$ & $12.2 \pm 4.2$ \\
Surface area of habitats $: \mathrm{a} \pm \mathrm{b}\left(\mathrm{m}^{2}\right)$ & $7.2 \pm 1.4$ & $3.6 \pm 0.8$ & $5.9 \pm 1.1$ \\
Distances between the sites occupied by & $12.3 \pm 5.2$ & $6.3 \pm 2.6$ & $10.7 \pm 4.3$ \\
Lymnaea truncatula and $L$. glabra $: \mathrm{a} \pm \mathrm{b}(\mathrm{m})$ & & & \\
Snail density in each habitat : $\mathrm{a} \pm \mathrm{b}$ & $26.0 \pm 10.7$ & $22.6 \pm 8.4$ & $23.0 \pm 9.5$ \\
Total area occupied $\left(\mathrm{m}^{2}\right)$ & 274 & 180 & 20.2 \\
Total area of meadows $(\mathrm{ha})$ & 36.5 & 28.7 & $0.11 \%$ \\
Percentage of meadow & $0.07 \%$ & $0.06 \%$ & \\
occupied by snails & & &
\end{tabular}

Table 3. Characteristics of sites inhabited by Lymnaea palustris and the total area of the meadows on acid soil. a (mean value). b (standard deviation.

Tableau 2. Caractéristiques des sites colonisés par Lymnaea palustris et la superficie totale des prairies sur sol acide. a (moyenne). b (écart type).

\begin{tabular}{llll}
\hline Parameters & Basse-Marche & Monts d'Ambazac & Plateaux de la Vienne \\
\hline Number of meadows & 3 & 3 & 3 \\
Total number of populations & 3 & 3 & 3 \\
Length of habitat $: \mathrm{a} \pm \mathrm{b}(\mathrm{m})$ & $8.0 \pm 1.4$ & $5.0 \pm 0.8$ & $9.9 \pm 1.8$ \\
Surface area of habitats $: \mathrm{a} \pm \mathrm{b}\left(\mathrm{m}^{2}\right)$ & $17.5 \pm 4.3$ & $10.3 \pm 2.3$ & $19.3 \pm 4.5$ \\
Distances between the sites occupied by & $15.4 \pm 6.4$ & $11.6 \pm 4.2$ & $13.7 \pm 5.7$ \\
Lymnaea glabra and $L$. palustris : a $\pm \mathrm{b}(\mathrm{m})$ & & & \\
Snail density in each habitat : $\mathrm{a} \pm \mathrm{b}$ & $7.5 \pm 3.8$ & $6.3 \pm 2.3$ & $58 \pm 4.5$ \\
Total area occupied $\left(\mathrm{m}^{2}\right)$ & 52.5 & 31 & 5.25 \\
Total area of meadows $(\mathrm{ha})$ & 8.33 & 2.45 & $0.11 \%$ \\
Percentage of meadow & $0.06 \%$ & $0.12 \%$ & \\
occupied by snails & & &
\end{tabular}


nature of habitat : ponds for Dreyfuss et al., open drainage ditches in our study. The differences between densities may be interpreted by hypothesizing that the species richness would be greater in a pond than in an open drainage system.

From the present study, it was found that the habitats of the three species were few in number in the meadows on acid soil (for example : a mean of 4.3 per pasture for L. truncatula). Their size was restricted and snail densities were low. These characteristics must be considered in the control of fasciolosis and one measure may be proposed. As these Lymnaea species act as intermediate hosts for this trematode in the region studied, fencing snail habitats would isolate cattle or sheep from snails and subsequently, stop the life cycle of $F$. hepatica, as demonstrated by Mage et al. (1989) in a farm located in the Correze Department (France). Subsequent transformation of fenced habitats using agronomic methods would eliminate snails by suppressing moisture excess. Extension of these measure to other regions or countries of western Europe, located on acid soil, might serve to eradicate fasciolosis from local cattle and sheep.

\section{References}

Bouix-Busson D. \& Rondelaud D. 1984. — Étude de relations entre deux espèces de limnées dans leurs habitats naturels. Rev. Méd. Vét., 135 : 449-457.

Busson P., Busson D., Rondelaud D. \& Pestre-Alexandre M. 1982. - Données expérimentales sur l'infestation des jeunes de cinq espèces de limnées par Fasciola hepatica . Ann. Parasitol. Hum. Comp., 57 : 555-563.

Dreyfuss G., Moukrim A., Rondelaud D. \& Vareille-Morel C. 1994. - Several field observations concerning infection of Lymnae palustris by Fasciola hepatica. J. Helminthol., 68 : 115-118.

Euzeby J. 1971. - Les maladies vermineuses des animaux domestiques et leurs-incidences sur la pathologie humaine. Tome II. Section 2. Book 1. Vigot Frères, Paris : 798 p.

Guy F., Rondelaud D., Botineau M., Dreyfuss G. \& Ghestem A. 1996. - Étude de relations entre les plantes les plus fréquentes et l'abondance de Lymnaea truncatula Müller, vecteur de Fasciola hepatica Linné, dans les prairies marécageuses sur sol acide. Rev. Méd. Vét., 147 : 465-570.
Kendall S.B. 1950. - Snail hosts of Fasciola hepatica in Britain. J. Helminthol., 24 : 63-74.

Mage C., Reynal P., Rondelaud D. \& Chasteloux C. 1989. - Mise en pratique du contrôle de l'infestation par Fasciola hepatica chez des bovins limousins. Bull. Group. Tech. Vét., $\mathrm{n}^{\circ} 347$ : 5-10.

Moens R. 1982. - Observations au sujet de la prédation de Zonitoides nitidus Müller sur Lymnaea truncatula Müller. Bull. Ecol., $13: 273-282$.

Pécheur M. 1974. - Lutte stratégique contre la distomatose. Comptes-Rendus de Recherches, Travaux du Centre de Recherches sur les Maladies Parasitaires des Animaux Domestiques, $\mathrm{n}^{\circ} 38$ : 85-150. I.R.S.I.A., Bruxelles.

Rondelaud D. 1975. - La prédation de Lymnaea (Galba) truncatula Müller par Zonitoides nitidus Müller, moyen de lutte biologique. Ann. Parasitol. Hum. Comp., 50 : 55-61.

Rondelaud D. 1977. - Résultats et problèmes posés par l'introduction de Mollusques Zonitidae dans quelques biotopes à Limnées tronquées en Indre et Haute-Vienne. Ann. Parasitol. Hum. Comp., $52: 521-530$.

Rondelaud D. 1981. - Le contrôle biologique de Lymnaea truncatula Müller. Bilan d'une expérimentation de neuf années en Haute-Vienne, France. Haliotis, $11: 213-224$.

Rondelaud D. 1982. - Le contrôle biologique par prédation de Lymnaea truncatula Müller. Étude expérimentale de la dynamique de cinq espèces de Mollusques après arrêt du traitement. Malacologia, 22 : 697-700.

Rondelaud D. 1988. - Le contrôle mixte et alterné de Lymnaea truncatula Müller : étude comparative de trois techniques pour l'épandage du molluscicide. Ann. Rech. Vét., $19: 279-282$.

Smith G. \& Wilson R.A. 1980. - Seasonal variations in the microclimate of Lymnaea truncatula habitats. J. Appl. Ecol., 17 : 329-342.

Stat-Itcf. 1988. - Manuel d'utilisation. Institut Technique des Céréales et des Fourrages, Service des Études Statistiques, Boigneville : $210 \mathrm{p}$.

Taylor E.L. 1965. - Fascioliasis and the liver-fluke. F.A.O. Agricultural Studies, Roma, $\mathrm{n}^{\circ} 64: 235 \mathrm{p}$.

Van den Bruel W.E. 1968. - Rapport d'activité 1968. Groupe de travail pour l'étude de la lutte contre les limnées. Station de Zoologie Appliquée de l'État, Centre de Recherches Agronomiques, Gembloux, Belgium : $62 \mathrm{p}$.

Vareille L., Vareille-Morel C., Dreyfuss G. \& Rondelaud D. 1996. - Les gîtes à limnées dans les prairies marécageuses sur sol acide : les effets d'impacts agricoles. Annls. Limnol., 32 : 97-104.

Vilks A. 1991. - Analyse chorologique de la flore vasculaire du Limousin. Thèse de Doctorat, Université de Limoges, $n^{\circ} 36: 247$. 